\title{
Conceptualizing Medical Resident's Journey through Wonderland of Clinical Practice: From transitional shock to role adaptation to independent practice
}

\author{
Marium Sohail ${ }^{1}$, Rahila Yasmeen ${ }^{2}$
}

\begin{abstract}
Objectives: To explore experiences of medical residents about stages and nature of transitional journey from induction into residency program to achievement of consultant title.

Methods: Qualitative phenomenological study was conducted at Sir Gangaram hospital and Fatima Memorial Hospital, Lahore for six months from Feb 2019-July 2019 after IRB/ERC approval from Islamic International Medical College (Ref\# Riphah/IIMC/ERC/19/0320). Using purposive criterion sampling, 16 semi-structured interviews in four departments, four strata of junior residents, senior residents, newly-qualified consultants, and supervising consultants with four participants each were conducted till theoretical saturation of data was achieved. After informed consent, audio recorded data was transcribed verbatim \& analyzed through Atlas.ti 7 using Interpretive Phenomenological Analysis. After Bracketing and horizontalization, data was coded line by line. Codes (324) were merged to categories (19) for structural and textural description. Composite description of phenomenon was done by abstraction of themes (eight for stages and two for nature of journey).

Results: Eight themes for stages as merriment, anguish, melancholy, acceptance and efforts, intensive learning, burnishing to shine, identity formation and intra-stage oscillations were identified. Two themes for journey's nature were exponential learning \& oscillating journey.

Conclusion: The transitional journey is a multi-stage complex, oscillating journey. An oscillating electron model is presented upon the findings of this study to explain resident transition
\end{abstract}

KEYWORDS: Education, Medical, Residency, Learning, Transitional journey.

doi: https://doi.org/10.12669/pjms.37.4.3853

How to cite this:

Sohail M, Yasmeen R. Conceptualizing Medical Resident's Journey through Wonderland of Clinical Practice: From transitional shock to role adaptation to independent practice. Pak J Med Sci. 2021;37(4):1048-1053. doi: https://doi.org/10.12669/pjms.37.4.3853

This is an Open Access article distributed under the terms of the Creative Commons Attribution License (http://creativecommons.org/licenses/by/3.0), which permits unrestricted use, distribution, and reproduction in any medium, provided the original work is properly cited.

1. Dr. Marium Sohail, MBBS, MHPE.

Assistant Professor / Director,

Department of Medical Education,

Poonch Medical College, Rawalakot, AJ\&K, Pakistan.

2. Dr. Rahila Yasmeen, BDS, DCPS- HPE, MHPE, PhD-HPE (Scholar).

Professor/ Director,

Department of Medical Education, DEAN RARE/ ORIC,

Riphah International University, Islamabad, Pakistan.

Correspondence:

Dr. Marium Sohail, MBBS, MHPE.

Assistant Professor / Director,

Department of Medical Education,

Poonch Medical College,

Rawalakot, AJ\&K, Pakistan.

Email: mariumsohail@gmail.com

* Received for Publication:

* Revision Received:

* Revision Accepted:
November 1, 2020

February 17, 2021

February 28, 2021

\section{INTRODUCTION}

Transition, in context to medical education refers to movement between different phases of medical training i.e. undergraduate, postgraduate and continuing medical education. Transitional shock is defined as "a crisis experienced by health professional and is marked by a temporary decrease in their ability to properly use biomedical knowledge in clinical reasoning and practice" ${ }^{1}$ Role adaptation refers to "acclimatization to transition or role in which an individual moves from being totally preoccupied with transition to integrating transition into his life by a changing one's behavior and attitude". ${ }^{2}$ 
Transition across different facets of educational, psychological and socio-cultural variations have a huge impact on identity formation and development of sense about one's self. ${ }^{3}$ Transition is a personalized endeavor but is challenging and stressful as one enters into a new learning environment. ${ }^{4,5}$ Worldwide studies indicate an increasing trend in negative effects like anxiety, depression and burnout in doctors. ${ }^{6}$ By the time physicians reach residency, rates of depression are four times the national average. ${ }^{7}$ One of every three budding physicians experiences an episode of major depression during their post graduate training. ${ }^{7}$ A recent rise in rate of suicide among Pakistani doctors with a greater propensity during residency period has been observed. ${ }^{8}$

Though the changes in responsibilities occur at every level of transition, yet the transition to "independent consultant practice" poses to be the most stressful because of the implicit assumption of the educators and clinicians that postgraduate medical students are "expert students" as they have successfully gained undergraduate degree, acquired residency position \& environment hasn't changed so their knowledge is continued and not re-situated. ${ }^{9,10}$ This assumption does not hold true as Postgraduate students are a heterogeneous and not a homogenous community \& all variables cannot be just negated and a general assumption be made for post graduate trainees. ${ }^{9}$

Stephens described objective career as externally defined reality of the career that comprise of person's work history while subjective career is typified in the attitudes, orientations, and perceptions about the career that are held by an individual. ${ }^{11}$ So, it's very important that subjective and objective career complement each other in order to make the transition between the professional stages easier, manageable and successful for health professional.

So, transition is conceptualized as a holistic and dynamic amalgamation of educational, psychological and socio-cultural variations. ${ }^{12}$ Conceptualizing progress of journey through insight into experience of residents in transitional period would be valuable for medical educators to identify the stages of journey and hence help in designing support interventions.

Research question: What are Medical resident's lived experiences about the stages of journey from transitional shock to role adaptation in clinical practice?

\section{METHODS}

A qualitative phenomenological study was conducted at Sir Gangaram Hospital and Fatima
Memorial Hospital, Lahore for six months from February 2019 - July 2019. Interview guide was constructed using theoretical framework (Fig.1), validated from experts and piloted prior to use. After Ethical approval, from IRB/ERC of Islamic International Medical College (Ref\# Riphah/IIMC/ ERC/19/0320). using purposive criterion sampling, 16 semi-structured interviews were conducted till theoretical data saturation was achieved. Four different clinical departments (medicine, surgery, gynecology and pediatrics), in four strata of junior residents, senior residents, newly-qualified and supervising consultants were involved in the study with four participants each. The interview was same for all strata, but prompts use for exploring different phases of transitional journey were different. After informed consent, audio recorded data was transcribed verbatim using anonymous names. Researcher also took notes of nonverbal cues during interviews in addition to audio recording. Excerpts in English were written as such while those in Urdu were translated by an expert in English language. Concurrent data analysis was done in order to modify data collection process and include the emerging themes in subsequent interviews. Data was analyzed through Atlas.ti 7 by Interpretive Phenomenological Analysis using codes from both analytical framework and in-vivo coding. After Bracketing and horizontalization, data was coded line by line. Codes (324) were merged to categories (19) for structural and textural description. Finally, the composite description of phenomenon was done by abstraction into eight themes outlining the stages \& two outlining nature of transitional journey.

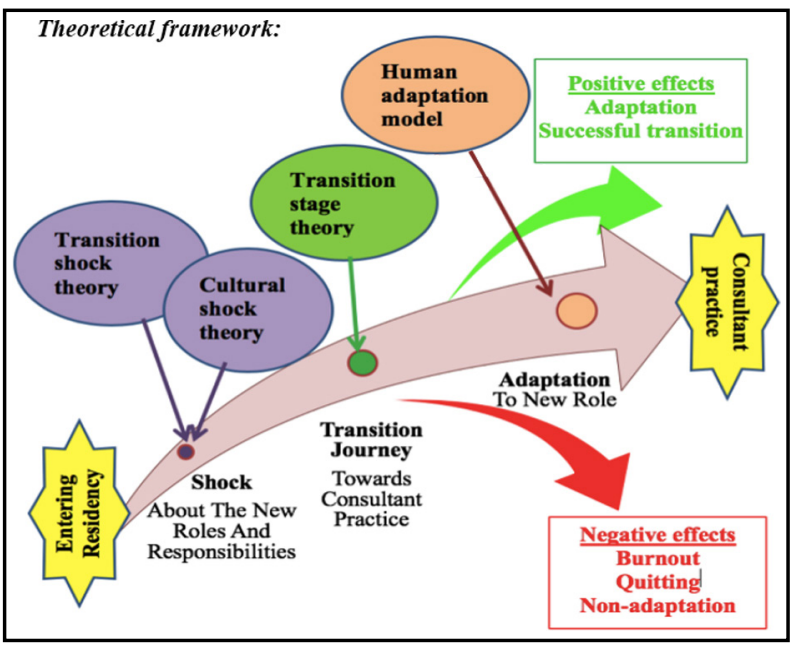

Fig.1: Theoretical framework for Transition phenomenon. ${ }^{2,13,14}$ 
Table-I: Stages of transitional journey with representative quotes .

\begin{tabular}{|c|c|c|c|c|}
\hline $\begin{array}{l}\text { Sr. } \\
\text { No }\end{array}$ & $\begin{array}{l}\text { Theme/ } \\
\text { (Frequency) }\end{array}$ & Category / Subtheme & $\begin{array}{l}\text { Codel } \\
\text { (frequency) }\end{array}$ & Representative Quote \\
\hline \multicolumn{5}{|c|}{ Stages of Journey } \\
\hline \multirow[b]{2}{*}{1} & & Dream come true & $\begin{array}{l}\text { Happiness } \\
(12)\end{array}$ & \multirow{2}{*}{$\begin{array}{l}\text { "I screamed, and I jumped and hugged my family and it was } \\
\text { a very different day... It's like you've achieved the greatest } \\
\text { thing....something like that." C2 }\end{array}$} \\
\hline & $\begin{array}{l}\text { Delectation } \\
\& \text { Merri- } \\
\text { ment (31) }\end{array}$ & Achievement & $\begin{array}{l}\text { Accomplishment } \\
(19)\end{array}$ & \\
\hline \multirow{4}{*}{2} & & Uncertainty & $\begin{array}{l}\text { Confusion and Distress } \\
(25)\end{array}$ & \multirow{2}{*}{$\begin{array}{l}\text { "... it was simply too much to take, I didn't know what to do, } \\
\text { how to do and when to do? I thought I wasn't capable of doing } \\
\text { all this, it's not my type..." A2 }\end{array}$} \\
\hline & & Lacking clarity & $\begin{array}{l}\text { Self-doubt } \\
(18)\end{array}$ & \\
\hline & $\begin{array}{l}\text { Angu } \\
\text { (74) }\end{array}$ & Reality check & $\begin{array}{l}\text { Discrepancy in reality } \\
\text { vs. expectations }(21)\end{array}$ & $\begin{array}{l}\text { "...life is tough and I have to work damn hard. Those bed of } \\
\text { roses vanished so suddenly, its different to What I imagined } \\
\text {.."C3 }\end{array}$ \\
\hline & & $\begin{array}{l}\text { Fear of medical } \\
\text { malpractice }\end{array}$ & $\begin{array}{l}\text { Afraid of negligence } \\
\text { in patient care }(10)\end{array}$ & $\begin{array}{l}\text { "I am accountable for patient. And that's not a small thing, } \\
\text { that's a life in my hand..." A1 }\end{array}$ \\
\hline \multirow{3}{*}{3} & \multirow{4}{*}{$\begin{array}{l}\text { Melan- } \\
\text { choly } \\
(23)\end{array}$} & $\begin{array}{l}\text { Shock and } \\
\text { depression }\end{array}$ & Newness is scary (8) & \multirow{3}{*}{$\begin{array}{l}\text { "I was afraid, I felt depressed coz everything felt new, no } \\
\text { friends, new place and me being naïve and depressed"C } 2 \\
\text { "..., I panicked and started crying, I shouted at nurse to save } \\
\text { him;..."D3 }\end{array}$} \\
\hline & & Emotional instability & Panic Attacks (11) & \\
\hline & & Turbulence & Crying (5) & \\
\hline \multirow{4}{*}{4} & & Self-realization & $\begin{array}{l}\text { Acceptance of short } \\
\text { comings (35) }\end{array}$ & $\begin{array}{l}\text { "...I am lacking in my knowledge and my clinical skills, and I } \\
\text { need to improve if I wish to survive" A2 }\end{array}$ \\
\hline & \multirow{3}{*}{$\begin{array}{l}\text { Acceptance } \\
\& \text { Dedicat- } \\
\text { ed Efforts } \\
(104)\end{array}$} & $\begin{array}{l}\text { Creating support } \\
\text { system around }\end{array}$ & $\begin{array}{l}\text { Create comfort zone } \\
\text { by seeking help }(18)\end{array}$ & \multirow{2}{*}{$\begin{array}{l}\text { "When I started to develop my rapport and good relationship } \\
\text { in the unit..., I started to feel relaxed." B3 } \\
\text {.... I regained rationality, from that day onward, I started } \\
\text { living my dream..."B2 }\end{array}$} \\
\hline & & Positive attitude & Learning to survive (29) & \\
\hline & & $\begin{array}{l}\text { Recognizing and } \\
\text { seizing learning } \\
\text { avenues }\end{array}$ & $\begin{array}{l}\text { Voluntary efforts for } \\
\text { learning (22) }\end{array}$ & $\begin{array}{l}\text { "... I was always asking questions } \mathcal{E} \text { searching for answers" } \\
\text { A2 }\end{array}$ \\
\hline \multirow{2}{*}{5} & \multirow{2}{*}{$\begin{array}{l}\text { Intensive } \\
\text { learning } \\
(67)\end{array}$} & Pacing up learning & $\begin{array}{l}\text { Eagerness to use oppor- } \\
\text { tunities to fullest (32) }\end{array}$ & \multirow{2}{*}{$\begin{array}{l}\text { "It's a dark tunnel with shining light at the end but you have } \\
\text { to look for the torches yourself to go to that end, I used to learn } \\
\text { from where ever I can, I used to look around for someone will- } \\
\text { ing to teach me, I even went to other hospitals to study...C3 }\end{array}$} \\
\hline & & $\begin{array}{l}\text { Intensive dedicated } \\
\text { efforts for learning }\end{array}$ & $\begin{array}{l}\text { Voluntary involvement } \\
\text { in opportunities (35) }\end{array}$ & \\
\hline \multirow{3}{*}{6} & \multirow{3}{*}{$\begin{array}{l}\text { Burnish to } \\
\text { shine (38) }\end{array}$} & $\begin{array}{l}\text { Recognizing facets } \\
\text { for improvement }\end{array}$ & $\begin{array}{l}\text { Acceptance of } \\
\text { limitations (9) }\end{array}$ & \multirow{2}{*}{$\begin{array}{l}\text { "One should always know his limitations, no one knows it all, } \\
\text { everyone has finite knowledge, if you don't know, seek help, } \\
\text { get someone on board, learn for next time"D3 }\end{array}$} \\
\hline & & Polishing to shine & $\begin{array}{l}\text { Working on weaknesses } \\
\text { (14) }\end{array}$ & \\
\hline & & $\begin{array}{l}\text { Self-efficacy and } \\
\text { self-regulation }\end{array}$ & $\begin{array}{l}\text { Periodic self-assessment } \\
\text { to drive learning } \\
\text { (15) }\end{array}$ & $\begin{array}{l}\text { "...You should know where to fine tune and where to initiate } \\
\text { crises management, YOU can only win, if u speak truth to } \\
\text { yourself" D4 }\end{array}$ \\
\hline \multirow[t]{2}{*}{7} & \multirow{2}{*}{$\begin{array}{l}\text { Identity } \\
\text { formation } \\
(41)\end{array}$} & Gaining insight & $\begin{array}{l}\text { Broadening of } \\
\text { professional mission } \\
\text { and vision }(15)\end{array}$ & \multirow{2}{*}{$\begin{array}{l}\text { "it's about equipping oneself with specialized knowledge, skills } \\
\text { and combat strategies for emergent patient need and personal } \\
\text { professional growth to make your own specialized worth in } \\
\text { healthcare setup and society" D3 }\end{array}$} \\
\hline & & $\begin{array}{l}\text { Establishing distinct } \\
\text { individualization }\end{array}$ & $\begin{array}{l}\text { Becoming Real } \\
\text { doctors (26) }\end{array}$ & \\
\hline \multirow{2}{*}{8} & \multirow{2}{*}{$\begin{array}{l}\text { Intra stage } \\
\text { oscillation } \\
\text { at exam } \\
\text { check point } \\
(48)\end{array}$} & $\begin{array}{l}\text { Crises due to } \\
\text { stress of IMM }\end{array}$ & $\begin{array}{l}\text { Shift of focus from } \\
\text { patient to exam due } \\
\text { to stress of IMM (29) }\end{array}$ & \multirow{2}{*}{$\begin{array}{l}\text { "I was so depressed before my IMM exam; I used to study all } \\
\text { night and was sleepy during my duty hours. My concentra- } \\
\text { tion shifted from patients to passing exam, I was stressed and } \\
\text { I still feel guilty about it" C3 }\end{array}$} \\
\hline & & $\begin{array}{l}\text { Burn Out before } \\
\text { Part } 2 \text { exam }\end{array}$ & $\begin{array}{l}\text { Exhausted and } \\
\text { depressed near } \\
\text { Part } 2 \text { exam (19) }\end{array}$ & \\
\hline
\end{tabular}




\section{RESULTS}

Sixteen members from four departments were divided into four groups on the basis of year of training. Of all the respondents $44 \%$ (7) were males while $56 \%$ (9) females. The average age of trainees was 30.9 years while that of supervisors was 55.3 years.

The residents identified eight stages of transition journey, Delectation and merriment followed by anguish, melancholy which then translates to acceptance and dedicated efforts, intensive learning, burnishing to shine and finally identity formation. However, residents experience intra stage oscillations at various points during the journey especially at exam check points. The residents described that there are two dimensions of journey as a doctor. One is the learning dimension which always increases exponentially while the other is the emotional dimension which is turbulent and oscillating. The nature of journey overall is determined more by the emotional dimension as it drastically effects on the learning and application of learning dimension.

Gender wise comparison between perspectives shows stages of melancholy, acceptance of reality, establishing self-efficacy and developing positive attitude towards learning were more strongly represented in female population while stages of lacking clarity anguish, creating support system and identity formation was reported more strongly in male population. The type of journey perceived as linear or exponential for learning and oscillating overall did not vary across gender.

Comparison of perspectives with respect to years of experience shows no significant difference in the stages of journey perception across different strata of years of experience. Those in initial years of experience had no idea about the later stages, they only gave the life experiences of the stage they are in. However, the resident's with more than three years of experience gave rich information about both early and late stages.

\section{DISCUSSION}

Eight stages for journey \& two for nature of journey are represented as Sohail's Oscillating electron model (Fig.2). This study has various similarities and differences across different spectrum of studies. Some stages are overlapping to those

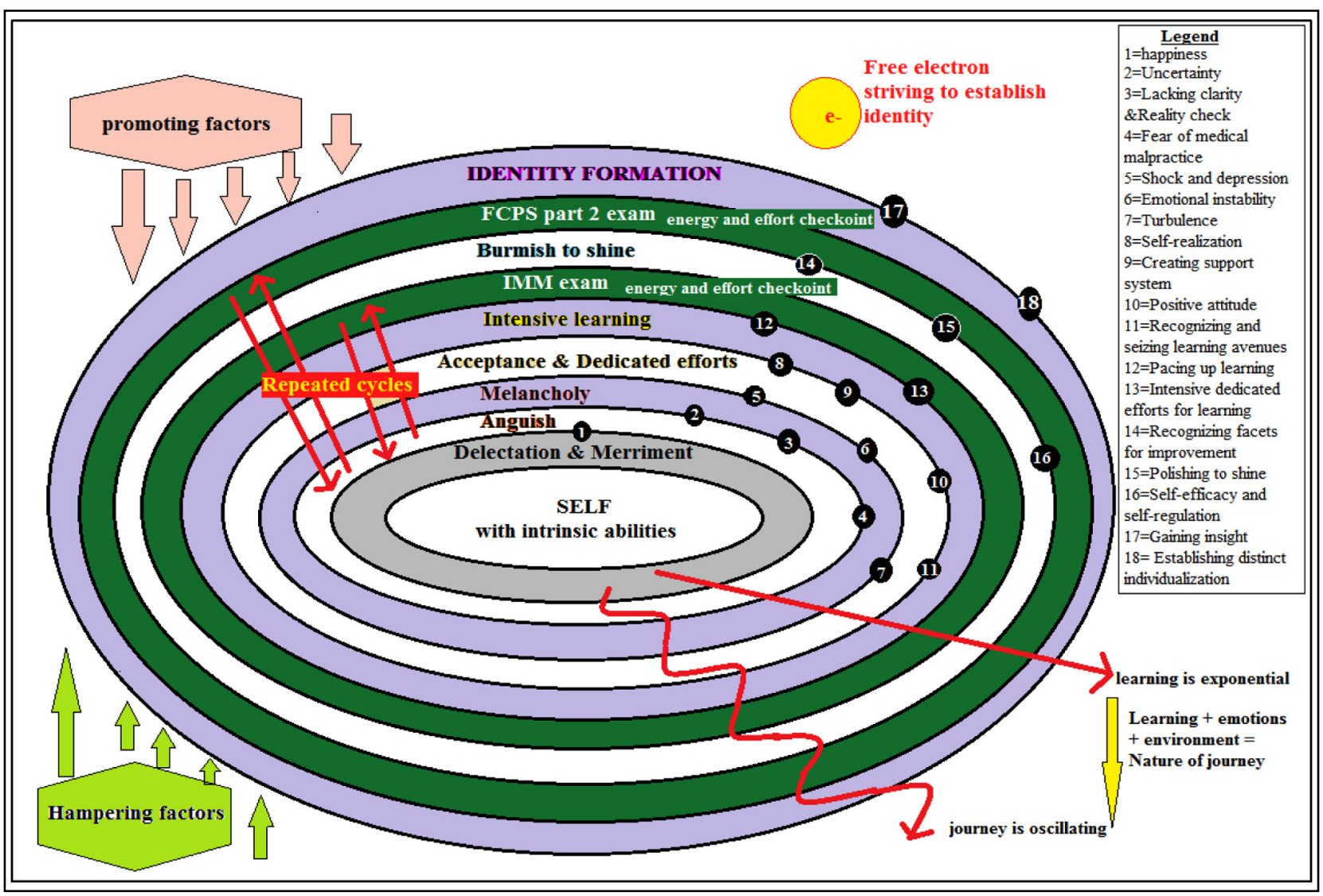

Fig.2: Sohail's oscillating electron model for transition. 
Table-II: Nature of Transition Journey with representative quotes

Findings of Nature of Transition Journey from the Data

\begin{tabular}{|c|c|c|c|c|}
\hline $\begin{array}{l}S / \\
N\end{array}$ & Theme & Category / Subtheme & Code & Representative Quote \\
\hline \multirow{4}{*}{1} & \multirow{4}{*}{$\begin{array}{l}\text { Learning } \\
\text { is expo- } \\
\text { nential } \\
(23)\end{array}$} & $\begin{array}{l}\text { Experiences drives } \\
\text { learning }\end{array}$ & $\begin{array}{l}\text { Learning from } \\
\text { experiences }(8)\end{array}$ & \multirow{2}{*}{$\begin{array}{l}\text { "Whenever you are thrown out to } \\
\text { experience something, you learn... learning } \\
\text { is invisible"D2 }\end{array}$} \\
\hline & & $\begin{array}{l}\text { Wanted and } \\
\text { unwanted learning }\end{array}$ & $\begin{array}{l}\text { Good or bad, you } \\
\text { always learn (6) }\end{array}$ & \\
\hline & & $\begin{array}{l}\text { Formal and } \\
\text { informal learning }\end{array}$ & $\begin{array}{l}\text { Learning occurs } \\
\text { everywhere (5) }\end{array}$ & \multirow{2}{*}{$\begin{array}{l}\text { "Someday you have an adrenaline rush and } \\
\text { learn more and then there are days when you } \\
\text { nearly learn nothing because of your laziness. } \\
\text { But even laziness teaches you what not to do... } \\
\text { laughter." B3 }\end{array}$} \\
\hline & & $\begin{array}{l}\text { Pace of learning } \\
\text { changes }\end{array}$ & $\begin{array}{l}\text { You learn: more or less } \\
\text { but never NO (4) }\end{array}$ & \\
\hline \multirow{5}{*}{2} & \multirow{5}{*}{$\begin{array}{l}\text { Journey is } \\
\text { oscillat- } \\
\text { ing } \\
(34)\end{array}$} & \multirow{4}{*}{$\begin{array}{l}\text { Back and forth } \\
\text { process }\end{array}$} & Bouncing back and fro (9) & \multirow{4}{*}{$\begin{array}{l}\text { "I think it's a way forward journey towards } \\
\text { your goals with turbulences here and there"B4 } \\
\text { "The process is linear for learning and spring } \\
\text { like motion for emotional journey. the more } \\
\text { you put pressure the more you bounce back.... } \\
\text { (laughter)" A2 }\end{array}$} \\
\hline & & & Ups and downs (6) & \\
\hline & & & $\begin{array}{l}\text { Way forward with } \\
\text { turbulence }(5)\end{array}$ & \\
\hline & & & Bouncing spring (10) & \\
\hline & & $\begin{array}{l}\text { Pendulum like } \\
\text { journey }\end{array}$ & Pendulous (4) & $\begin{array}{l}\text { "it's like a pendulum like journey, here to there, } \\
\text { there to here, till you reach } 12 \text { to strike and } \\
\text { stay" D3 }\end{array}$ \\
\hline
\end{tabular}

reported in literature while some sub stages are distinctive. Draper J reported that transitional path is individualized yet variable \& similar milestones across transitional journey can be identified despite of contextual differences. ${ }^{15}$ Wegner and Snyder Communities of practice theory states that people with similar domain of interest, works together to share ideas and practice which ultimately leads to improved practice in the domain, as they learn how to do better what they are doing. The life cycle of CoP has potential, coalescing, maturing, active, dispersed/repository stages. ${ }^{16}$ The pattern of emotions experienced by doctors in this study align clearly with the life events transition reported by Fisher, Porteous, Wall and Duschers adding validity to the findings and reinforcing the results of my study. ${ }^{13.14} \cdot{ }^{17,18}$ Hopson's reported stages of excitement \& honeymoon, uncertainty, depression and crises, quitting or letting go, partial recovery, exploration, nesting and ultimately transformation in a linear graphical form with positive and negative deflections. ${ }^{19}$ Fisher reported Anxiety, happiness, threat, guilt, depression, gradual acceptance and moving forwards, while Porteous identified uncertainty, learning to survive, looking out for help and moving forwards as important stages. ${ }^{17,20}$ Getting ready to move, moving in, organizing to move out and moving out were identified by Wall as four distinct features of transitional journey. ${ }^{21}$ Draper also highlighted similar stages in his study on nurses. ${ }^{15}$ Hardy and nightingale reported phases of elation, denial, doubt, crises and recovery for radiographic technicians. ${ }^{22}$ As per Duchscher the nurses move from Doing to Being to Knowing stage. ${ }^{13.14}$ After transition shock the nurses recover, learn and re-learn to reveal true potential within self. The final stage is to know and accept the real self. This linear trajectory of experiential learning corresponds to the stages of acceptance, intensive learning, polishing to shine and identity formation in my study. The sub-stages of fear of medical malpractice, self-reflection for realization and gaining insight are distinctive in my study.

Draper \& Maria stated that transition is an organic journey with varied experiences, variable expressions and an individual endeavor with indefinite boundaries. ${ }^{15,23}$ Colbert-getz states that experiences vary which causes fluctuating states of emotional, physical and social instability. ${ }^{24}$ All these studies have similar perspectives explained as in this study as an oscillating journey with a net forward direct for learning. The oscillation during the transitional journey is due to intrinsic and extrinsic factors playing in the picture. In contrast 
to it, Duchscher identifies a linear trajectory of experiences for nurses in his study. ${ }^{14} \mathrm{He}$ explained the journey in equivalence to time to regain their rationality. ${ }^{13}$ This study gives a contrasting view and may be attributed to the difference in the context and working of doctors and nurses. ${ }^{25}$

The oscillating electron model (Fig.2) depicts oscillating movement across the shells which keeps electron moving up and down with the difference in energy i.e. the resident oscillates between stages with the presence of extent of promoting and hampering factors. If hampering factors are more backward oscillations are more. If promoting factors are strong forward oscillations are strong. The learning is exponential and always increases while the journey is oscillating.

It is a qualitative study hence its non-generalizable to wider audience. Such a study has never been conducted for medical or dental doctors hence comparison of results from similar context is unavailable. Due to time constraints lived experiences were explored retrospectively only. Longitudinal exploration can be done for re-verification and triangulation of findings. Educational interventions can be planned using oscillating electron model. The study can be conducted across different cultures, strata and specialties to establish a comparison.

\section{CONCLUSION}

The stages identified for the resident's transitional journey are merriment, anguish, melancholy, acceptance and efforts, intensive learning, burnishing to shine and identity formation. Interspaced among these stages are two checkpoints for the learning, effort and energy assessment. The residents oscillate between stages and substages; some stages might be skipped for each individual depending upon their context. Learning is exponential while the journey is perceived to be oscillating. An oscillating electron model is presented to explain the resident transition.

Grant Support E Financial Disclosures: None.

\section{REFERENCES}

1. Godefrooij MB, Diemers AD, Scherpbier AJJA. Students ' perceptions about the transition to the clinical phase of a medical curriculum with preclinical patient contacts: A focus group study. BMC Med Educ. 2010;10(28):1-9. doi: 10.1186/1472-6920-10-28

2. Schlossberg NK. A Model for Analysing Human Adaptation to Transition. Couns Psychol. 1979;9(2):20-38. doi: 10.1186/1472-6920-10-28

3. Teunissen PW. Experience, trajectories, and reifications: an emerging framework of practice-based learning in healthcare workplaces. Adv Heal Sci Educ. 2015;20(4):843-856. doi: 10.1007/s10459-014-9556-y

4. Zhou Y, Todman J, Topping KJ, Jindal-Snape D. Cultural and educational adaptation during transition from Chinese to UK universities. In: Educational Transitions. Routledge; 2009:200-218. ISBN/9780203859124
5. Halpern JY. Reasoning about uncertainty. MIT press; 2017

6. Andrew LB. Physician Suicide. MEDSCAPE [Internet]. 2018;Aug. Available from: https://emedicine.medscape.com/ article/806779-overview

7. Tasi J, UNICEF. Physicians, Depression and Burnout [Internet]. 2018. Available from: https://blogs.scientificamerican.com/observations/physicians-depression-and-burnout/

8. Mahmood K. Time to Act - Alarming Rise in Suicides Among Medical Professionals in Pakistan. J Coll Physicians Surg Pak [Internet] 2016;26(12):947-949.

9. O'Donnell VL, Tobbell J, Lawthom R, Zammit M. Transition to postgraduate study: Practice, participation and the widening participation agenda. Act Learn High Educ. 2009;10(1):26-40. doi: $10.1177 / 1469787408100193$

10. Houdyshellm M. Academic integrity in an emerging democracy: How university students in a former Soviet Republic balance achievement and success in education. J Ethn Cult Stud. 2017;4(1):14

11. Stephens GK. Crossing internal career boundaries: The state of research on subjective career transitions. J Manage. 1994;20(2):479-501. doi: 10.1016/0149-2063(94)90024-8

12. James G. A narrative inquiry perspective into coping mechanisms of international postgraduate students ' transition experiences. Am J Qual Res. 2018:2(1):41-56

13. Duchscher JEB. Transition shock: the initial stage of role adaptation for newly graduated Registered Nurses. J Adv Nurs 2009;65(5):1103-1113. doi: 10.1111/j.1365-2648.2008.04898.x

14. Duchscher JB. A Process of Becoming: The Stages of New. 442 J Contin Educ Nurs. 2008;39(10):421-426. doi: 10.3928/00220124 20081001-03

15. Draper J. 'Doing it for real now'-The transition from healthcare assistant to newly qualified nurse: A qualitative study. Nurse Educ Today. 2018;66:90-95. doi: 10.1016/j.nedt.2018.04.008

16. Ray D. Life cycle of communities of practice. Encycl Communities Pract Inf Knowl Manag. 2005;323-326. doi: 10.4018/978-1-59140556-6.ch055

17. Porteous DJ, Machin A. The lived experience of first year undergraduate student nurses: A hermeneutic phenomenological study. Nurse Educ Today [Internet]. 2018;60:56-61. Available from: doi: 10.1016/j. nedt.2017.09.017

18. Wall P, Fetherston C, Browne C. Understanding the enrolled nurse to registered nurse journey through a model adapted from Schlossberg's transition theory. Nurse Educ Today. 2018;67:6-14. doi: 10.1016/j.nedt.2018.04.017

19. Hopson B, Adams J. Towards an understanding of transitions. Transit Underst Manag Pers Chang London, Martin Robertson. 1976

20. Fisher JM. The Process of personal Transition (Fisher's personal transition curve). Hum Resour Dev Int J. 2012;(Revised):257-254

21. Wall P. Experiences of nursing students in a Bachelor of Nursing program as they transition from Enrolled Nurse to Registered Nurse. Murdoch University. [Internet]. 2016. Available from: http://researchrepository.murdoch.edu.au/id/eprint/30987/

22. Hardy M, Nightingale J. Conceptualizing the Transition from Advanced to Consultant Practitioner : Career Promotion or Significant Life Event? J Med Imaging Radiat Sci [Internet]. 2014;45(4):356-364. doi: 10.1016/j.jmir.2014.09.007 doi: 10.1016/j.jmir.2014.09.007

23. Maria H, Shuk yu, Stanley LKK, Mei WL. The transition challeng es faced by new graduate nurses in their first year of professional experience. J Nurs Heal Care. 2017;5(1):1-8.

24. Colbert-getz JM, Baumann S, Shaffer K, Lamb S, Janet E, Rainey $\mathrm{R}$, et al. What's in a Transition? An Integrative Perspective on Transitions in Medical Education. Teach Learn Med [Internet]. 2016;28(4):347-352. doi: 10.1080/10401334.2016.1217226

25. Yeo E, Yi JH, Im K. Development of the Transition Shock Scale for Newly Graduated Nurses. Korean Soc Nurs Sci. 2017;47(5):589599. doi: 10.4040/jkan.2017.47.5.589

Authors Contribution: MS: Conceived, designed, collected data, did phenomenological analysis, writing, editing of manuscript and is responsible for integrity of the study. RY: Supervised, did review and final approval of manuscript. 